\title{
HUBUNGAN SANITASI RUMAH TINGGAL DENGAN KEJADIAN INFEKSI SALURAN PERNAPASAN AKUT PADA ANAK 0-5 TAHUN DI DESA BABAKAN KECAMATAN PANGANDARAN KABUPATEN PANGANDARAN
}

\author{
Aldi Septian ${ }^{1)}$, Khomsatun ${ }^{1)}$, Lagiono ${ }^{1)}$ \\ 1) Jurusan Kesehatan Lingkungan, Politeknik Kesehatan Kemenkes Semarang
}

\begin{abstract}
Abstrak
Latar belakang kejadian ISPA merupakam salah satu penyebab kematian tersering pada anak di Negara berkembang, dengan gejala demam, batuk, pilek, infeksi telinga dan radang tenggorokan. Kelompok yang paling berisiko adalah balita, anak-anak, dan orang lanjut usia, terutama di negaranegara dengan pendapatan per kapita rendah dan menengah. Penelitian ini bertujuan untuk mengetahui sanitasi rumah tinggal yang berhubungan dengan kejadian ISPA. Jenis penelitian yang digunakan adalah observasional dengan pendekatan case control (penelitian jenis analitik observasional yang dilakukan dengan cara membandingkan antara kelompok kasus sebanyak 30 (penderita ISPA) dan kelompok kontrol berdasarkan status paparannya sebanyak 30. Analisis yang di gunakan yaitu uji Chi-Square dan untuk menguji terhadap risiko dengan dihitung Odds Ratio (OR) dan uji Regresi Logistik. Hasil penelitian ini adalah luas ventilasi (p: 0,000, OR: 9,036), kepadatan hunian (p: 0,020, OR: 3,500), kepemilikan lubang asap dapur (p: 0,003, OR: 5,231), jenis dinding (p: 1,000, OR: 1,000) dan jenis lantai tidak dapat dianalisis menggunakan uji chi square. Hasil uji analisis regresi logistik yang paling dominan yaitu luas ventilasi dengan nilai $\mathrm{B}=2,662$, $\mathrm{p}=0,000$ dan $\mathrm{OR}=9,036$. Simpulan dari penelitian ini yaitu tidak ada hubungan antara jenis dinding dan jenis lantai, serta ada hubungan yang signifikan antara luas ventilasi, kepadatan hunian dan kepemilikan lubang asap dapur dengan kejadian ISPA. Disarankan bagi masyarakat untuk menigkatkan perilaku hidup bersih dan sehat, Diharapkan masyarakat yang mempunyai balita dapat memperbaiki kondisi lingkungan fisik rumah, membuka ventilasi rumah agar ada pergantian udara, menyapu lantai setiap hari agar terhindar dari debu dan memisahkan kamar balita dengan orang tua agar tidak tertular penyakit ISPA.
\end{abstract}

Kata Kunci: Sanitasi Rumah Tinggal, Dengan Kejadian ISPA pada Balita

\begin{abstract}
Background ARI is one of the most common causes of death in developing countries children, with symptoms of fever, cough, runny nose, ear infections and sore throat. . The groups most at risk are toddlers, children, and the elderly, especially in countries with low and medium per capita income. This study aims to determine residential sanitation associated with ARI cases. This type of research is observational with a case control approach (observational analytic type of research conducted by comparing 30 case groups (patients with ARI) and control groups based on exposure status which is 30. The analysis used is the ChiSquare test and to test on risk with calculated Odds Ratio $(O R)$ and the Logistic Regression test. The results of this study are ventilation area ( $p: 0,000$, OR: 9,036), occupancy density (p:0.020, OR: 3,500), ownership of kitchen smoke pits (p: 0.003, OR: 5.231), wall type ( $p: 1,000$, OR : 1,000) and the type of floor cannot be analyzed using the chi square test. The most dominant logistic regression analysis results are ventilation area with a value of $B=2,662, p=0,000$ and $O R=9,036$. The conclusion from this study is that there is no relationship between wall type and floor type, and there is a significant relationship between ventilation area, occupancy density and ownership of kitchen smoke holes with the incidence of ARI. It is recommended for the community to improve clean and healthy living behavior. It is expected that people who have toddlers can improve the physical condition of the house, open ventilation of the house so that there is air change, sweep the floor every day to avoid dust and separate the toddler's room from parents so the disease not spread.
\end{abstract}

Keywords: Residential of Sanitation, and ARI Occurrence in toddlers 


\section{Pendahuluan}

ISPA menjadi salah satu penyebab utama morbiditas dan mortalitas penyakit menular di dunia. Hampir empat juta orang meninggal akibat ISPA setiap tahun, 98\%-nya disebabkan oleh infeksi saluran pernapasan bawah. Kelompok yang paling berisiko adalah balita, anak-anak, dan orang lanjut usia, terutama di negara-negara dengan pendapatan per kapita rendah dan menengah ( WHO, 2007).

Kematian akibat ISPA lebih didominasi balita usia 1-4 tahun yaitu lebih dari 2 juta kematian tiap tahunnya, ini juga berarti 1 dari 5 orang balita di dunia meninggal setiap harinya. Saat ini penyakit ISPA menjadi perhatian khusus baik pada tingkat rumah sakit maupun puskesmas yang ada di negara maju sampai pada negara berkembang seperti Indonesia dimana ISPA menjadi penyakit nomor satu yang sering dijumpai pada setiap daftar 10 penyakit terbanyak (Agustina dkk, 2013).

Kasus ISPA di Indonesia pada tiga tahun terakhir menempati urutan pertama penyebab kematian bayi yaitu sebesar 24,46\% (2013), 29,47\% (2014) dan 63,45\% (2015). Selain itu, penyakit ISPA juga sering berada pada daftar 10 penyakit terbanyak di rumah sakit (Kemenkes RI, 2015). Terdapat lima Provinsi dengan ISPA tertinggi yaitu Nusa Tenggara Timur (41,7\%), Papua (31,1\%), Aceh $(30,0 \%)$, Nusa Tenggara Barat $(28,3 \%)$, dan Jawa Timur $(28,3 \%)$. Karakteristik penduduk dengan ISPA yang tertinggi berdasarkan umur terjadi pada kelompok umur 1- 4 tahun $(25,8 \%)$. Penyakit ini lebih banyak dialami pada kelompok penduduk kondisi ekonomi menengah ke bawah (Kemenkes, 2013).

Ruang lingkup kesehatan lingkungan antara lain mencakup perumahan, pembuangan kotoran manusia, penyediaan air bersih, pembuangan sampah, air limbah. Adapun yang dimaksud usaha kesehatan lingkungan adalah usaha untuk memperbaiki atau mengoptimalkan kondisi lingkungan hidup manusia agar menjadi media yang baik untuk terwujudnya kesehatan optimum bagi manusia. Rumah merupakan sebagai bangunan berfungsi untuk tempat tinggal dan untuk sarana pembinaan keluarga. Kondisi rumah yang tidak memenuhi syarat kesehatan dapat menimbulkan gangguan kesehatan manusia dan dapat mempengaruhi keseimbangan serta ketentraman bagi penghuni rumah tersebut.( WHO, 2017).

Faktor lingkungan merupakan faktor yang paling erat hubungannya dengan penularan penyakit terutama penyakit menular. Salah satunya diantaranya penularan penyakit Infeksi Saluran Pernafasan Akut (ISPA). Sanitasi rumah yang tidak memenuhi persyaratan kesehatan seperti kelembapan, suhu, dan pencahayaan alami yang tidak memenuhi syarat dapat menjadi lingkungan yang baik bagi perkembangbiakan bakteri ISPA terutama penularan pada balita yang belum memiliki kekebalan tubuh ( Yusuf dan Sulistyorini, 2005).
Dinas Kesehatan Kabupaten Pangandaran, Jawa Barat, mengatakan bahwa grafik penyebaran penyakit menular di wilayah Kabupaten Pangandaran mengalami naik turun. Berdasarkan laporan Bidang Pemberantasan Penyakit dan Penyehatan Lingkungan (P2PL) Kabid P2PL Dinkes Pangandaran, mengatakan bahwa penyakit yang rentan menular di Pangandaran, diantaranya ISPA (Infeksi Saluran Pernafasan Akut). Penularan influenza pada Balita seringkali terjadi, Influenza akibat virus ditandai demam tinggi tiba-tiba, batuk kering, sakit kepala dan sendi, lemas, radang tenggorokan, pilek dan batuk yang berlangsung hingga dua minggu. Dampak yang paling dirasakan adalah sesak nafas, pilek, demam, kelelahan dan kelemahan sehingga balita berkurang aktifitasnya, padahal proses tumbuh kembang pada balita sangatlah penting. Jika tidak segera ditangani dengan benar hal ini dapat menyebabkan penyakit lainnya seperti Otitis media, Faringtitis, Pneumonia dan penyakit infeksi lainnya (Mardiah,2017).

Berdasarkan Dinas Kesehatan Jawa barat pada tahun 2003, infeksi saluran pernafasan akut merupakan urutan pertama penyakit terbanyak pada balita, yaitu sekitar 33,4\% (Nurhidayah, 2010). Pada tahun 2018 di Kabupaten Pangandaran yang merupakan salah satu wilayah di Jawa Barat, pneumonia merupakan urutan kedua penyebab terjadinya ISPA pada anak kurang dari lima tahun setelah penyakit gastritis. Hasil observasi awal yang telah dilakukan peneliti ditemukan kasus ISPA (Infeksi Saluran Pernafasan Akut) pada balita, tahun 2018 didapatkan sebanyak kasus 3.306 atau sebesar $68,2 \%$ penderita yang ditemukan dan ditangani di wilayah kerja Puskesmas Pangandaran.

\section{Bahan dan Metode}

Jenis penelitian yang digunakan adalah observasional dengan pendekatan case control (penelitian jenis analitik observasional yang dilakukan dengan cara membandingkan antara kelompok kasus (penderita ISPA) dan kelompok kontrol berdasarkan status paparannya). Penelitian case control dapat digunakan untuk mencari hubungan seberapa jauh sanitasi rumah tinggal mempengaruhi terjadinya suatu penyakit.

Variabel bebas yang digunakan pada penelitian ini sebanyak 5 variabel yaitu luas ventilasi, kepadatan hunian, lubang asap dapur, jenis dinding dan jenis lantai. Serta variable terikat yaitu kejadian ISPA.

Analisis univariat untuk menyajikan data statistik table, dan Analisis bivariate yang digunakan yaitu Chi Square untuk mengetahui apakah variabel bebas dan variabel terikat ada hubungannya dengan menggunakan rumus hitung X2 (Chi-Square) dan untuk menguji terhadap risiko dengan dihitung Odds Ratio (OR). Serta Analisis Multivariat menggunakan Uji Regresi Logistic. 


\section{Hasil dan Pembahasan}

\section{A. Data umum Lokasi Penelitian}

1. Keadaan Geografis

Desa Babakan memiliki luas wilayah 604 hektare yang terdiri dari 5 (lima) Dusun, yaitu Dusun Bojongsari, Dusun Karanggedang, Dusun Kalapatiga, dusun Kamurang dan Dusun Bojongkarekes. Dimana Desa ini terletak sekitar 3 $\mathrm{Km}$ dari ibu kota kecamatan. Secara Geografis, Desa Babakan berbatasan langsung dengan beberapa wilayah sekitarnya, meliputi ;

a. Sebelah Utara `: Desa Sukahurip

b.Sebelah Selatan: Samudera Hindia

c.Sebelah Timur : Desa Putrapinggan

d.Sebelah Barat : Desa Pananjung

\section{Keadaan Demografi}

Kondisi demografi Desa Babakan meliputi jumlah dan pertumbuhan penduduk, komposisi penduduk menurut jenis kelamin. Penduduk di Desa Babakan memiliki jumlah penduduk dengan keseluruhan 9.949 jiwa dengan penduduk perempuan 4.900 dan laki-laki 4.549. Penduduk dari desa Babakan ini kebanyakan bermatapencaharian sebagai nelayan. Selain itu petani juga mendominasi mata pencaharian dari penduduknya menyusul pekerjaan lainnya seperti PNS, pedagang dan lainnya.

3. Keadaan Kesehatan Lingkungan di Desa Babakan Pangandaran

Hasil observasi yang peneliti lakukan, masih kurangnya kesadaran masyarakat untuk menjaga kebersihan lingkungan, seperti membersihkan halaman rumah, hygiene sanitasi, kurangnya pencahayaan rumah, debu, sehingga sanitasi lingkungan di Desa Babakan ini belum diterapkan dengan baik karena rendahnya komitmen para pihak terkait.

\section{B. Data Khusus}

1. Gambaran Karakteristik Responden

a. Gambaran Karakteristik Responden Menurut Kelompok Umur.

Tabel 4.1 Gambaran Karakteristik Responden Menurut Kelompok Umur

\begin{tabular}{crrrrrrr}
\hline \multirow{2}{*}{ Kelompok Umur } & \multicolumn{2}{c}{ Kasus } & \multicolumn{2}{c}{ Kontrol } & \multicolumn{2}{c}{ Total } \\
\cline { 2 - 8 } & $\mathrm{N}$ & $\begin{array}{c}\text { Persen } \\
(\%)\end{array}$ & $\mathrm{N}$ & $\begin{array}{c}\text { Persen } \\
(\%)\end{array}$ & $\mathrm{N}$ & $\begin{array}{c}\text { Persen } \\
(\%)\end{array}$ \\
\hline 0 Tahun & 3 & 10,0 & 3 & 10,0 & 6 & 10,3 \\
\hline 1 Tahun & 5 & 16,7 & 5 & 16,7 & 10 & 16,6 \\
\hline 2 Tahun & 6 & 20,0 & 7 & 23,3 & 13 & 21,6 \\
\hline 3 Tahun & 6 & 20,0 & 5 & 16,7 & 11 & 18,3 \\
\hline 4 Tahun & 5 & 16,7 & 5 & 16,7 & 10 & 16,6 \\
\hline 5 Tahun & 5 & 16,7 & 5 & 16,7 & 10 & 16,6 \\
\hline Total & 30 & 100,0 & 30 & 100,0 & 60 & 100,0 \\
\hline
\end{tabular}

Gambaran Karakteristik responden menurut kelompok umur paling tinggi pada kasus yaitu kelompok umur 2-3 tahun sebesar $18,3 \%$, sedangkan pada kelompok kontrol paling tinggi yaitu kelompok umur 2 tahun sebesar $21,6 \%$. b. Gambaran Karakteristik Responden Menurut Jenis Kelamin.

Tabel 4.2 Gambaran Karakteristik Menurut Jenis Kelamin

\begin{tabular}{crrrrrr}
\hline \multirow{2}{*}{ Jenis Kelamin } & \multicolumn{2}{c}{ Kasus } & \multicolumn{2}{c}{ Kontrol } & \multicolumn{2}{c}{ Total } \\
\cline { 2 - 8 } & $N$ & $\begin{array}{c}\text { Persen } \\
(\%)\end{array}$ & $N$ & $\begin{array}{c}\text { Persen } \\
(\%)\end{array}$ & $N$ & $\begin{array}{c}\text { Persen } \\
(\%)\end{array}$ \\
\hline Laki-laki & 17 & 56,7 & 18 & 60 & 35 & 58,4 \\
\hline Perempuan & 13 & 43,3 & 12 & 40 & 25 & 41,6 \\
\hline Total & 30 & 100,0 & 30 & 100,0 & 60 & 100,0 \\
\hline
\end{tabular}

Gambaran karakteristik responden menurut jenis kelamin dari total responden 60 orang, terdiri dari 35 laki - laki dengan persentase $58,4 \%$ dan 25 perempuan dengan persentase $41,6 \%$. Pada kelompok kasus jenis kelamin laki-laki lebih banyak yaitu $56,7 \%$ dibanding perempuan yaitu $43,3 \%$, sedangkan pada kelompok kontrol jenis kelamin perempuan lebih banyak yaitu 58,4\% dibanding laki - laki yaitu $41,6 \%$.

2. Univariat

a. Luas Ventilasi

\begin{tabular}{|c|c|c|c|c|}
\hline \multirow[b]{2}{*}{ Luas Ventilasi Rumah } & \multicolumn{2}{|c|}{ Kasus } & \multicolumn{2}{|c|}{ Kontrol } \\
\hline & $\mathrm{N}$ & $\begin{array}{c}\text { Persen } \\
(\%)\end{array}$ & $\mathrm{N}$ & $\begin{array}{c}\text { Persen } \\
(\%)\end{array}$ \\
\hline Memenuhi Syarat & & 30 & 23 & 76,7 \\
\hline $\begin{array}{l}\text { Tidak Memenuhi } \\
\text { Syarat }\end{array}$ & 2 & 70 & 7 & 23,3 \\
\hline Total & 3 & 100,0 & 30 & 100,0 \\
\hline
\end{tabular}

Tabel 4.3 Distribusi Kasus dan Kontrol Menurut luas ventilasi rumah

Pada tabel 4.3 menunjukkan bahwa responden pada kelompok kasus memiliki luas ventilasi tidak memenuhi syarat lebih besar yaitu $70 \%$ dibandingkan dengan luas ventilasi yang memenuhi syarat yaitu $30 \%$, sedangkan responden pada kelompok kontrol memiliki luas ventilasi tidak memenuhi syarat lebih kecil yaitu 23,3\% dibandingkan dengan luas ventilasi yang memenuhi syarat yaitu $76,7 \%$.

b. Kepadatan Hunian

Tabel 4.4 Distribusi Kasus dan Kontrol Menurut Kepadatan Hunian.

\begin{tabular}{|c|c|c|c|c|}
\hline \multirow[b]{2}{*}{ Kepadatan Hunian } & \multicolumn{2}{|c|}{ Kasus } & \multicolumn{2}{|c|}{ Kontrol } \\
\hline & $\mathrm{N}$ & $\begin{array}{c}\text { Persen } \\
(\%)\end{array}$ & $\mathrm{N}$ & $\begin{array}{c}\text { Persen } \\
(\%)\end{array}$ \\
\hline Memenuhi Syarat & 9 & 30 & 18 & 60 \\
\hline Tidak Memenuhi Syarat & 21 & 70 & 12 & 40 \\
\hline Total & 30 & 100,0 & 30 & 100,0 \\
\hline
\end{tabular}

Pada tabel 4.4 menunjukkan bahwa responden pada kelompok kasus memiliki kepadatan hunian tidak memenuhi syarat lebih besar yaitu $70 \%$ dibandingkan dengan kepadatan hunian yang memenuhi syarat yaitu $30 \%$, sedangkan responden pada kelompok kontrol sama memiliki kepadatan hunian tidak memenuhi syarat lebih kecil yaitu $40 \%$ 
dibandingkan dengan kepadatan hunian yang memenuhi syarat yaitu $60 \%$.

\section{c. Lubang Asap Dapur}

Tabel 4.5 Distribusi Kasus dan Kontrol Menurut Lubang Asap Dapur.

\begin{tabular}{|c|c|c|c|c|}
\hline \multirow[b]{2}{*}{ Lubang Asap dapur } & \multicolumn{2}{|c|}{ Kasus } & \multicolumn{2}{|c|}{ Kontrol } \\
\hline & $\mathrm{N}$ & $\begin{array}{c}\text { Persen } \\
(\%)\end{array}$ & $\mathrm{N}$ & $\begin{array}{c}\text { Persen } \\
(\%)\end{array}$ \\
\hline Memenuhi Syarat & 13 & 43,3 & 24 & 80 \\
\hline Tidak Memenuhi Syarat & 17 & 56,7 & 6 & 20 \\
\hline Total & 30 & 100,0 & 30 & 100,0 \\
\hline
\end{tabular}

Pada tabel 4.5 menunjukkan bahwa responden pada kelompok kasus memiliki lubang asap dapur tidak memenuhi syarat lebih kecil yaitu 43,4\% dibandingkan dengan lubang asap dapur yang memenuhi syarat yaitu $56,7 \%$, sedangkan responden pada kelompok kontrol sama memiliki lubang asap dapur tidak memenuhi syarat lebih kecil yaitu 20\% dibandingkan dengan lubang asap dapur yang memenuhi syarat yaitu $80 \%$.

\section{d. Jenis Dinding}

Tabel 4.6 Distribusi Kasus dan Kontrol Menurut Jenis Dinding

\begin{tabular}{lrrrr}
\hline \multirow{2}{*}{ Jenis Dinding } & \multicolumn{2}{c}{ Kasus } & \multicolumn{2}{c}{ Kontrol } \\
\cline { 2 - 5 } & $N$ & $\begin{array}{c}\text { Persen } \\
(\%)\end{array}$ & N & \multicolumn{1}{c}{$\begin{array}{c}\text { Persen } \\
(\%)\end{array}$} \\
\hline Memenuhi Syarat & 22 & 73,3 & 22 & 73,3 \\
Tidak Memenuhi Syarat & 8 & 26,7 & 8 & 26,7 \\
\hline Total & 30 & 100,0 & 30 & 100,0 \\
\hline
\end{tabular}

Pada tabel 4.6 menunjukkan bahwa responden pada kelompok kasus memiliki jenis dinding tidak memenuhi syarat lebih kecil yaitu 26,7\% dibandingkan dengan jenis dinding yang memenuhi syarat yaitu $26,7 \%$, sedangkan responden pada kelompok kontrol sama memiliki jenis dinding tidak memenuhi syarat lebih kecil yaitu 26,7\% dibandingkan dengan jenis dinding yang memenuhi syarat yaitu $73,3 \%$.

e. Jenis Lantai

Tabel 4.7 Distribusi Kasus dan Kontrol Menurut Jenis Lantai

\begin{tabular}{lrrrr}
\hline \multirow{2}{*}{ Jenis Lantai } & \multicolumn{2}{c}{ Kasus } & \multicolumn{2}{c}{ Kontrol } \\
\cline { 2 - 5 } & $N$ & $\begin{array}{c}\text { Persen } \\
(\%)\end{array}$ & N & \multicolumn{2}{c}{$\begin{array}{c}\text { Persen } \\
(\%)\end{array}$} \\
\hline Memenuhi Syarat & 30 & 100 & 30 & 100 \\
Tidak Memenuhi Syarat & 0 & 0 & 0 & 0 \\
\hline Total & 30 & 100,0 & 30 & 100,0 \\
\hline
\end{tabular}

Pada tabel 4.7 menunjukkan bahwa responden pada kelompok kasus dan kelompok kontrol yang memiliki jenis lantai rumah tidak memenuhi syarat 0 dengan persentase $0 \%$ dan jenis lantai rumah memenuhi syarat 30 dengan persentase $100 \%$.
3. Bivariat

a. Luas Ventilasi

Tabel 4.8 Hubungan Luas Ventilasi dengan Kejadian ISPA

\begin{tabular}{|c|c|c|c|c|c|c|c|c|}
\hline \multirow{2}{*}{$\begin{array}{l}\text { Luas } \\
\text { Ventilasi }\end{array}$} & \multicolumn{2}{|c|}{ Kasus } & \multicolumn{2}{|c|}{ Kontrol } & \multicolumn{2}{|c|}{ Total } & \multicolumn{2}{|c|}{$\mathrm{Cl} 95 \%$} \\
\hline & $\mathrm{N}$ & $\%$ & & $\%$ & $\mathrm{~N}$ & $\%$ & Lower & Upper \\
\hline $\begin{array}{l}\text { Tidak } \\
\text { Memenuhi }\end{array}$ & 22 & 73,3 & 7 & 23,3 & 29 & 48,6 & \multirow{3}{*}{2,802} & \multirow{3}{*}{29,134} \\
\hline Syarat & & & & & & & & \\
\hline $\begin{array}{l}\text { Memenuhi } \\
\text { Syarat }\end{array}$ & 8 & 26,7 & 23 & 76,7 & 31 & 51,4 & & \\
\hline \multirow[t]{2}{*}{ Total } & 30 & 100,0 & 30 & 100,0 & 60 & 100,0 & & \\
\hline & \multicolumn{2}{|c|}{$p=0,000$} & \multicolumn{2}{|c|}{$O R=9,036$} & & & & \\
\hline
\end{tabular}

Pada tabel 4.8 menunjukkan bahwa luas ventilasi pada kelompok kasus yang tidak memenuhi syarat memiliki proposi lebih besar yaitu $73,3 \%$, dibandingkan dengan kelompok kontrol 23,3\%. Sedangkan luas ventilasi yang memenuhi syarat pada kelompok kasus lebih kecil yaitu 26,7\% dibandingkan kelompok kontrol yaitu $76,7 \%$.

Penelitian ini sejalan dengan penelitian yang dilakukan oleh Lady Diana BR Sinuraya (2017), yang menunjukkan bahwa ada hubungan antara ventilasi dengan kejadian ISPA di Kabupaten Karo dan balita tinggal di tempat yang ventilasi yang tidak memenuhi syarat mempunyai risiko terkena ISPA 3,1 kali lebih besar dibanding dengan balita yang tinggal di rumah yang ventilasinya memenuhi syarat.

Dari hasil observasi diperoleh sebagian besar luas ventilasi rumah responden kasus tidak memenuhi syarat karena kebanyakan rumah responden berbentuk minimalis dengan luas ruangan yang tidak begitu besar dan pembuatan design ventilasinya juga tidak besar dan membuat sinar matahari masuk kedalam rumah tidak menyinari seluruh ruangan.Hal ini disebabkan karena masyarakat tidak menghiraukan besar ventilasi tapi lebih memperdulikan bagaimana mereka cukup tidur dan tempat pertukaran udara mereka sering menggunakan pintu yakni dengan cara membuka pintu rumah dengan lebar. Rumah dengan luas ventilasi yang tidak memenuhi syarat besar ventilasi $>10 \%$ dari luas lantai ini dapat menimbulkan peningkatan kepengapan dan kelembaban ruangan sehingga memudahkan penularan penyakit.

b. Kepadatan Hunian

Tabel 4.9 Hubungan Kepadatan Hunian dengan Kejadian ISPA

\begin{tabular}{|c|c|c|c|c|c|c|c|c|}
\hline \multirow{2}{*}{$\begin{array}{c}\text { Kepadatan } \\
\text { Hunian }\end{array}$} & \multicolumn{2}{|c|}{ Kasus } & \multicolumn{2}{|c|}{ Kontrol } & \multicolumn{2}{|c|}{ Total } & \multicolumn{2}{|c|}{$\mathrm{Cl} 95 \%$} \\
\hline & $\mathrm{N}$ & $\%$ & $\mathrm{~N}$ & $\%$ & $\mathrm{~N}$ & $\%$ & Lower & Upper \\
\hline $\begin{array}{l}\text { Memenuhi } \\
\text { Syarat }\end{array}$ & 9 & 30 & 18 & 60 & 27 & 45 & & \\
\hline $\begin{array}{l}\text { Tidak } \\
\text { Memenuhi } \\
\text { Syarat }\end{array}$ & 21 & 70 & 12 & 40 & 33 & 55 & 1,201 & 10,196 \\
\hline Total & $\frac{30}{p}$ & $\begin{array}{l}100,0 \\
0,020\end{array}$ & $\begin{array}{l}30 \\
\mathrm{OR}=\end{array}$ & $\begin{array}{l}100,0 \\
3,500\end{array}$ & 60 & 100,0 & & \\
\hline
\end{tabular}

Pada tabel 4.9 menunjukkan bahwa kepadatan hunian pada kelompok kasus yang tidak memenuhi syarat memiliki proposi lebih besar yaitu $70 \%$, dan 
kelompok kontrol 40\%. Sedangkan kepadatan hunian yang memenuhi syarat pada kelompok kasus lebih kecil yaitu $30 \%$ dan kelompok kontrol yaitu $60 \%$.

Penelitian ini sejalan dengan penelitian yang dilakukan oleh Lady Diana BR Sinuraya (2017) hal ini menunjukkan bahwa ada hubungan antara kepadatan hunian dengan kejadian ISPA di Kabupaten Karo dan balita tinggal di tempat yang kepadatan hunian yang tidak memenuhi syarat mempunyai risiko terkena ISPA 4,5 kali lebih besar dibanding dengan balita yang tinggal di tempat yang kepadatan huniannya memenuhi syarat.

Sebagian besar responden memiliki rumah dengan kepadatan yang tidak memenuhi syarat, karena dari hasil observasi kebanyakan responden memiliki luas kamar kurang dari $8 \mathrm{~m} 2$ dan luas ventilasi yang kurang dari $10 \%$ di huni oleh 2 orang dewasa dan 2 orang anak (Permenkes, 2011). Sehingga dapat mempengaruhi penyebaran penyakit menular dalam kecepatan transmisi mikroorganisme. Luas rumah yang sempit dengan jumlah anggota keluarga yang banyak menyebabkan rasio penghuni dengan luas rumah tidak seimbang yang memungkinkan bakteri maupun virus dapat menular melalui pernafasan dan penghuni rumah satu ke penghuni rumah lainnya.

\section{c. Lubang Asap Dapur}

Tabel 4.10 Hubungan Lubang Asap Dapur dengan Kejadian ISPA

\begin{tabular}{|c|c|c|c|c|c|c|c|c|}
\hline \multirow{2}{*}{$\begin{array}{l}\text { Lubang } \\
\text { Asap } \\
\text { Dapur }\end{array}$} & \multicolumn{2}{|c|}{ Kasus } & \multicolumn{2}{|c|}{ Kontrol } & \multicolumn{2}{|c|}{ Total } & \multicolumn{2}{|c|}{$\mathrm{Cl} 95 \%$} \\
\hline & $\mathrm{N}$ & $\%$ & $\mathrm{~N}$ & $\%$ & $\mathrm{~N}$ & $\%$ & Lower & Upper \\
\hline $\begin{array}{l}\text { Memenuhi } \\
\text { Syarat }\end{array}$ & 13 & 43,3 & 24 & 80 & 37 & 61,6 & & \\
\hline $\begin{array}{l}\text { Tidak } \\
\text { Memenuhi } \\
\text { Syarat }\end{array}$ & 17 & 56,7 & 6 & 20 & 23 & 38,4 & 1,657 & 16,515 \\
\hline Total & 30 & 100,0 & 30 & 100,0 & 60 & 100,0 & & \\
\hline & & 0,003 & OR & $=5,231$ & & & & \\
\hline
\end{tabular}

Pada tabel 4.12 menunjukkan bahwa lubang asap dapur pada kelompok kasus yang tidak memenuhi syarat memiliki proposi lebih besar yaitu $56,7 \%$, dan kelompok kontrol 20\%. Sedangkan lubang asap dapur yang memenuhi syarat pada kelompok kasus lebih kecil yaitu $43,3 \%$ dan kelompok kontrol yaitu $80 \%$.

Penelitian ini tidak sejalan dengan penelitian yang dilakukan oleh Vovi Noviyanti (2012), yang menunjukkan bahwa tidak ada hubungan antara kepemilikan lubang asap dengan kejadian ISPA dan balita tinggal di tempat yang dapurnya tidak memenuhi syarat mempunyai risiko terkena ISPA 1,876 kali lebih besar dibandingkan balita yang tinggal di rumah dengan kondisi dapur yang memenuhi syarat. d. Jenis Dinding

Tabel 4.11 Hubungan Jenis Dinding dengan ISPA

\begin{tabular}{lcccccccc}
\hline \multicolumn{1}{c}{ Jenis } & \multicolumn{2}{c}{ Kasus } & \multicolumn{2}{c}{ Kontrol } & \multicolumn{2}{c}{ Total } & \multicolumn{2}{c}{ Cl 95\% } \\
\cline { 2 - 8 } \multicolumn{1}{c}{ Dinding } & $\mathrm{N}$ & $\%$ & $\mathrm{~N}$ & $\%$ & $\mathrm{~N}$ & $\%$ & Lower & Upper \\
\hline Memenuhi & 22 & 73,3 & 22 & 73,3 & 44 & 73,3 & & \\
$\begin{array}{l}\text { Syarat } \\
\text { Tidak }\end{array}$ & 8 & 26,7 & 8 & 26,7 & 16 & 26,7 & 0,318 & 3,140 \\
$\begin{array}{l}\text { Memenuhi } \\
\text { Syarat }\end{array}$ & & & & & & & & \\
\hline Total & 30 & 100,0 & 30 & 100,0 & 60 & 100,0 & \\
\hline \multicolumn{5}{c}{$\mathrm{p}=1,000$} & $\mathrm{OR}=1,000$ & & & \\
\hline
\end{tabular}

Pada tabel 4.11 menunjukkan bahwa jenis dinding pada kelompok kasus yang tidak memenuhi syarat memiliki proposi sama yaitu $26,7 \%$, dan kelompok kontrol 26,7\%. Sedangkan jenis dinding yang memenuhi syarat pada kelompok kasus memiliki proporsi sama yaitu 73,3\% dan kelompok kontrol yaitu 73,3\%.

Penelitian ini tidak selaras dengan penelitian yang dilakukan Ardinasari Eiyta(2016). dengan nilai p-value yang diperoleh adalah 0,004, yaitu ada hubungan yang bermakna antara jenis dinding dengan kejadian ISPA. Hasil penelitian dari 52 responden di wilayah Desa Guyung Kecamatan Gerih didapatkan bahwa 40 rumah responden memiliki jenis dinding yang sudah memenuhi syarat, yaitu dari batu bata dan batako. Hal ini menunjukkan bahwa jenis dinding rumah responden sebagian besar sudah memenuhi syarat.

e. Jenis Lantai

Tabel 4.12 Hubungan Jenis Lantai Rumah dengan Kejadian ISPA

\begin{tabular}{|c|c|c|c|c|c|c|c|c|}
\hline \multirow{2}{*}{$\begin{array}{l}\text { Jenis } \\
\text { Lantai }\end{array}$} & \multicolumn{2}{|c|}{ Kasus } & \multicolumn{2}{|c|}{ Kontrol } & \multicolumn{2}{|c|}{ Total } & \multicolumn{2}{|c|}{$\mathrm{Cl} 95 \%$} \\
\hline & $\mathrm{N}$ & $\%$ & $\mathrm{~N}$ & $\%$ & $\mathrm{~N}$ & $\%$ & Lower & Upper \\
\hline Tidak & & & & & & & & \\
\hline Memenuhi & 0 & 0 & 0 & 0 & 0 & 0 & & \\
\hline $\begin{array}{l}\text { Syarat } \\
\text { Memenuhi } \\
\text { Syarat }\end{array}$ & 30 & 100,0 & 30 & 100,0 & 60 & 100,0 & - & \\
\hline Total & 30 & 100,0 & 30 & 100,0 & 60 & 100,0 & & \\
\hline
\end{tabular}

Pada tabel 4.12 menunjukkan bahwa responden kelompok kasus dan kelompok kontrol memiliki jenis lantai rumah yang memenuhi syarat (kedap air) $100 \%$. Sehingga jenis lantai rumah tidak dapat dianalisis menggunakan Uji Chi-Square.

Penelitian ini selaras dengan penelitian yang dilakukan Lady Diana BR Sinuraya (2017), dengan nilai p-value yang diperoleh adalah 1.000 sehingga tidak ada hubungan yang bermakna antara jenis lantai dengan kejadian ISPA. Berdasarkan pengamatan di lapangan diperoleh sebagian rumah responden jenis lantainya sudah kedap air dan terbuat dari keramik dan plaster, sehingga mudah dibersihkan dari debu. Sebagian lantai masih dari tanah tidak kedap air, masih berdebu jika di sapu dapat menyebabkan ISPA pada balita. Lantai yang baik adalah tidak berdebu pada musim kemarau dan tidak basah dimusim hujan. Lantai yang tidak standar standar merupakan media perkembangbiakan bakteri dan virus penyebab ISPA. 
3. Multivariat

\begin{tabular}{|c|c|c|c|c|}
\hline No & Komponen & B & Nilai P-value & OR \\
\hline 1 & Luas Ventilasi & 2,662 & 0,000 & 9,036 \\
\hline 2 & Kepadatan Hunian & 1,748 & 0,020 & 3,500 \\
\hline 3 & Lubang Asap Dapur & 2,473 & 0,003 & 5,231 \\
\hline & Constant & $-3,244$ & 0,000 & 0,039 \\
\hline
\end{tabular}

Hasil akhir dari uji regresi logistic dari ke-3 variabel yang paling dominan berhubungan dengan kejadian ISPA pada balita adalah variable luas ventilasi dengan nilai tertinggi yaitu 9,036 hal ini menunjukan bahwa luas ventilasi merupakan variable yang paling berpengaruh terhadap sanitasi rumah tinggal dengan kejadian ISPA dibandingkan dengan variable yang lain.

Hasil uji multivariate ini sesuai dengan hasi penelitian Aditya Rahman (2015). Yang menyatakan bahwa syarat variabel kandidat multivariat yang dimana akan masuk dalam analisis multivariat yaitu variabel yang mempunyai nilai $\mathrm{p}<0,25$. Dari ke 5 (lima) variabel yang masuk dalam kandidat multivariate setelah dilakukan analisis dengan menggunakan SPSS menggunakan metode Backward-LR yang paling signifikan atau paling dominan dengan kejadian ISPA yaitu ventilasi $(\mathrm{P}=0,003, \mathrm{OR}=9,611)$ dan kepadatan penghuni $(\mathrm{P}=0,000, \mathrm{OR}=17,297)$.

Hasil uji multivariate ini sejalan dengan penelitian Freska (2018). Menyatakan ada 4 variabel yang signifikan dengan kejadian ISPA. Hal ini menunjukan bahwa pengaruh luas ventilasi rumah 4,199 kali lebih dominan dengan kejadian ISPA pada balita di wilayah kerja Puskesmas Perawatan lawe perbunga dengan nilai $\operatorname{Exp}(\mathrm{B})$ 0,011 (CI:95\%, 0,091).

\section{Kesimpulan}

a. Responden pada kelompok kasus memiliki luas ventilasi yang tidak memenuhi syarat lebih besar yaitu 22 (70\%), kepadatan hunian yang tidak memenuhi syarat sama yaitu 21 (70\%), kepemilikan lubang asap dapur yang tidak memenuhi syarat $17(56,7 \%)$, kelompok kasus dan kontrol memiliki jenis dinding yang memenuhi syarat sama yaitu $22(73,3 \%)$, kelompok kasus dan kontrol memiliki jenis lantai rumah memenuhi syarat $100 \%$.

b. 2. Hasil uji statistik menunjukkan bahwa ( $p=0,000$ dan $O R=9,036(2,802$ dan 29,134)) berarti ada hubungan yang signifikan pada variabel luas ventilasi dengan kejadian ISPA.

c. 3. Hasil uji statistik menunjukkan bahwa ( $p=0,020$ dan $O R=3,500(1,201$ dan 10,196)) berarti ada hubungan yang signifikan pada variabel kepadatan hunian dengan kejadian ISPA.

d. 4. Hasil uji statistik menunjukkan bahwa $(\mathrm{p}=0,003$ dan $\mathrm{OR}=5,231$ (1,657 dan 16,515)) berarti ada hubungan yang signifikan pada variabel lubang asap dapur dengan kejadian ISPA.

e. 5. Hasil uji statistik menunjukkan bahwa $(\mathrm{p}=1,000$ dan $\mathrm{OR}=1,000(0,318$ dan 3,140$))$ berarti tidak ada hubungan yang signifikan pada variabel jenis dinding dengan kejadian ISPA.

f. 6. Jenis lantai rumah tidak dapat di analisis menggunakan uji chi square

g. 7. Hasil uji regresi logistic pada variabel luas ventilasi $(B=2,662, p=0,000$ dan OR 9,036), Kepadatan hunian $(B=1,743, p=0,020$ dan OR $3,500)$, lubang asap dapur $(B=2,473, p=0,003$ dan $\mathrm{OR}=5,231$ ), luas ventilasi rumah paling dominan berisiko lebih besar terkena penyakit ISPA pada anak 0-5 tahun.

\section{Daftar Pustaka}

Agustina, et al. 2013. "Hubungan Status Gizi dengan Infeksi Saluran Pernafasan akut di Desa Pelem Pada Balita di Wilayah Kerja Puskesmas Bendo Kabupaten Kediri"

Ardinasari, Eiyta. 2016. Buku Pintar Mencegah dan Mengobati

\&Anak.Jakarta:Bestari.

Penyakit Bayi

Ditjen PPM dan PL (2002) Pedoman Teknis Penilaian Rumah sehat . Jakarta : Departemen Kesehatan R.I.

Kemenkes RI. 2013. Riset Kesehatan Dasar 2010. Badan Penelitian dan Pengembangan Kementrian RI: Jakarta.
Kemenkes, 2015. Kasus ISPA pada Tiga Tahun Terakhir Sebagai Penyebab Kematian Pada Balita. Jakarta 2015

Kementerian Kesehatan RI. (2012). profil data kesehatan indonesia. Depkes RI, Jakarta.

Kepmenkes RI No. 829/Menkes/SK/VII/1999 tentang Persyaratan Kesehatan Perumahan.

Mardiah, 2017. "pencegahan penularan ispa (infeksi saluran pernafasan akut) dan perawatannya pada balita dirumah di kabupaten pangandaran".

Notoatmodjo, Soekidjo. (2003). Ilmu Kesehatan Masyarakat "Prinsip-prinsip dasar", Rineka Cipta, Jakarta. 
Noviyanti, Vovi. 2012. Faktor-faktor yang mempengaruhi kejadian penyakit ISPA di sekitar wilayah tempat pembuangan akhir sampah tamangapa kota Makassar.

Organizatin, W. H. (2008). Infeksi Saluran Pernapasan Akut (ISPA) yang Cenderung Menjadi Epidemi dan Pandemi. Pedoman Interim WHO

Sinuraya, BR Diana Lady. 2017. Faktor risiko yang mempengaruhi kejadian ISPA pada balita di desa Singgamanik Kecamatan Munte Kabupaten Karo.
Sulistyorini, 2005. "Determinan Sanitasi Rumah Dan Sosial Ekonomi Keluarga Terhadap Kejadian Ispa Pada Anak Balita Serta Manajemen Penanggulangannya Di Puskesmas"

Widodo, 2001. Rumah Sebagai Tempat Hunian Dan Sarana pembinaan Keluarga.

World Health Organization (WHO). 2007. Pencegahan dan pengendalian Infeksi saluran pernafasan Akut (ISPA) yang cenderung menjadi epidemic dan pandemic di fasilitasi pelayanan kesehatan. 